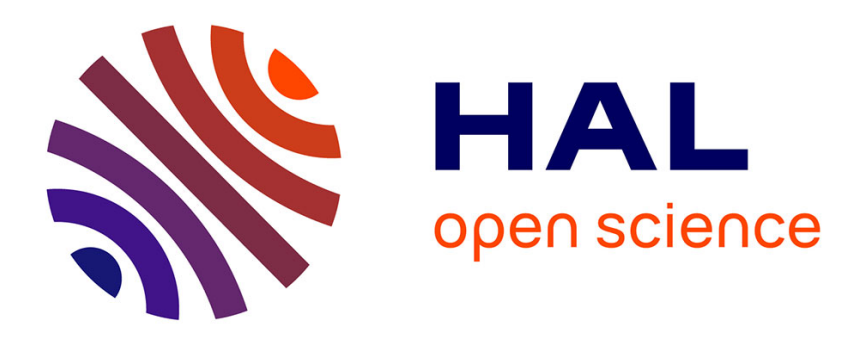

\title{
Equal Opportunity in the Educational System and the Ethics of Responsibility.
}

Philippe de Villé

\section{To cite this version:}

Philippe de Villé. Equal Opportunity in the Educational System and the Ethics of Responsibility.. 2003. halshs-00603558

\section{HAL Id: halshs-00603558 \\ https://shs.hal.science/halshs-00603558}

Submitted on 26 Jun 2011

HAL is a multi-disciplinary open access archive for the deposit and dissemination of scientific research documents, whether they are published or not. The documents may come from teaching and research institutions in France or abroad, or from public or private research centers.
L'archive ouverte pluridisciplinaire $\mathbf{H A L}$, est destinée au dépôt et à la diffusion de documents scientifiques de niveau recherche, publiés ou non, émanant des établissements d'enseignement et de recherche français ou étrangers, des laboratoires publics ou privés. 


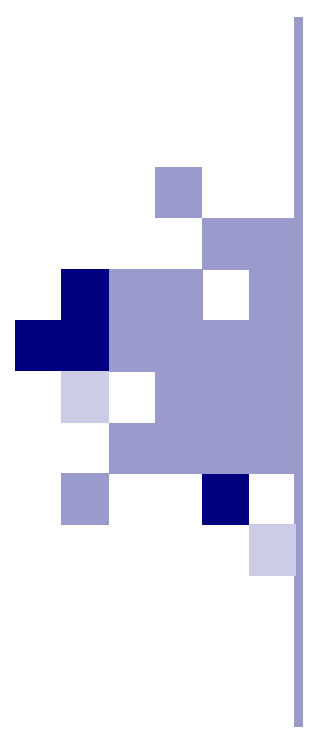

CAHIER DE RECHERCHE dU GIRSEF

\title{
Equal Opportunity in the Educational \\ System and the Ethics of Responsibility
}

\section{Philippe De Villé *(IRES - GIRSEF)}

\author{
$\mathrm{N}^{\circ} 17 \bullet \mathrm{MARCH} 2003 \bullet$
}

- This paper has benefited from the support of the GIRSEF ARC research convention 97-02/209 of the Ministry of Higher Education and Scientific Research of the "Communauté Française de Belgique". It was written during my stay at the National Center for the Study of Privatisation in Education (NCSPE), Teacher's College, Columbia University, whose support is gratefully acknowledged.

*Professor of Economics, IRES and GIRSEF, 1 Place Montesquieu, 1348 Louvain-la-Neuve, Belgium, deville@ires.ucl.ac.be

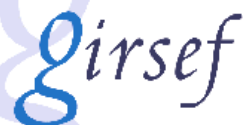




\section{Le GIRSEF dans I'Université Catholique de Louvain}

L'éducation et la formation constituent des enjeux fondamentaux pour la société contemporaine. Interpellée par ces enjeux au regard des ses missions de recherche et de service à la société, l'Université a créé le GIRSEF : un lieu clairement identifiable dédié au développement de la recherche sur les dynamiques de transformation et de restructuration des systèmes d'éducation et de formation. Le GIRSEF a pour vocation de penser rigoureusement et globalement ces transformations en matière éducative ainsi que leurs implications sociales, culturelles et politiques, dans une perspective pluridisciplinaire (économie, sociologie, psychopédagogie,...). Les recherches qui s'y déroulent se font en lien étroit avec les activités de recherche des départements des différentes disciplines concernées.

La série des Cahiers de recherche du GIRSEF a pour objectif de diffuser les résultats des travaux menés au sein du GIRSEF auprès d'un public de chercheurs en sciences de l'éducation et de la formation ainsi qu'auprès des acteurs et décideurs de ces deux mondes. 


\section{Table des matières}

Abstract

1. Equal opportunity and the ethics of responsibility in education

2. Compensation versus natural reward

3. Choices, responsibility and child's schooling behaviour : a re-examination

4. More on the child's schooling achievement function: complementarity and school organisation

5. Concluding remarks

References 


\begin{abstract}
To be "just", a society should treat every child fairly, i.e. with equal concern with regard to his potential education achievements. A person's educational achievements is indeed essential for enhancing her capacity for self-development: ideally, they all should have the same opportunities for achieving a level of formal education that would allow them to further study and compete for the jobs that they are fit for. This requires that the allocation of public educational resources among children should satisfy some principles of justice. Alongside objectives in terms of equality of "extended resources", recent theories of justice have emphasised the importance of taking into account personal responsibility in the design of equal opportunity policies. Allocation rules of educational expenditures should compensate for difference in non-controllable (by the child) determinants of school achievements, but also let freely determined effort levels to be adequately rewarded.
\end{abstract}

Some allocation rules inspired by those requirements are discussed and the underlying reasoning for considering them are questioned along four different dimensions : 1 . the child's effort and its determinants 2. the child's "school achievement production function": i.e. substitutability or complementarity between the determinants of school achievements, 3. the importance of externalities within the class room (peer effects) 4 . the structure of the secondary school curricula. It is argued that all those dimensions are justifying the importance given to equal opportunity considerations but are also essential in identifying what should be the basic features of an equal opportunity strategy. In particular, they suggest that the focus on responsibility as one essential dimension in the design of such a strategy might be misplaced. But it also points out that an equal opportunity strategy consisting of compensating for inequality in endowments among children should also carefully incorporate various incentives mechanisms that will both enhance the effectiveness of the equality of opportunity strategy while contributing at the same time to the maximisation of the total human capital acquired by the children.

Section 1 discusses what is the "equal opportunity" approach to schooling, its raison d'être. Section 2 reviews and critically discuss the basic "equal opportunity" model and its implications. Sections 3 and 4 present modifications and extensions of this framework and section 5 concludes with some policy recommendations. 


\section{Equal opportunity and the ethics of responsibility in education}

It has long been recognised that, there are wide disparities among children in their probabilities of achieving a certain level of formal education, at the primary level as well as the secondary level of schooling ${ }^{1}$. Despite effort made to reduce those disparities (positive discrimination), those disparities seem to persist ${ }^{2}$. They are related to a multitude of factors. Differences in parents behaviour towards schooling (parents' ambitions for their children education, their ability and commitment to help and support them in the studying process, but also parentsteachers-school relations), in family income and wealth (even if education is "free") and in other socio-economically related cultural factors (cultural and scientific "climate" or environment), have been made responsible for quite a long time for the existence of those inequalities ${ }^{3}$. Useless to say, correlation among those factors might also be significant.

Recent work has also been referring to a more controversial factor, because of its many possible interpretations, the so-called child's "innate ability" or "talents" for education. There has been considerable discussion as to what importance could be given to such "innate ability" and what it really consists in, the extreme position denying its existence altogether and making all our "initial" differences in capacity for learning dependent upon contextual factors, especially socio-economic background. However, nobody can at least deny the existence of natural, i.e. men-

\footnotetext{
${ }^{1}$ It has been estimated that, for the Belgian French-speaking community, less than a third of a given cohort of children entering in the first grade will have access to higher education. Even more dramatic, $37 \%$ of that same cohort will not even obtain their secondary school certificate.

${ }^{2}$ In Europe, we are just celebrating more or less the twentieth anniversary of the "ZEP's" (Priority Education Zone) that have been the landmark of the positive discrimination approach to equal opportunity.

3 There is a very extensive literature on school achievements "production function": for a general introduction to the subject, see Belfield (2000), pp.75-78.
}

tal, handicaps (negative talents !). Nevertheless it should not be too much of a concern for us at this stage. It will be later on. Suffice to say that we now recognise the existence of a range of exogenous factors (factors beyond the control of the child himself) that affect a child's capacity to learn and to obtain a certain level of formal educational achievement.

A second class of exogenous factors that might affect school achievements is the amount of resources received by the child for accomplishing his study requirements. These resources are those provided by the budget that either the private or the public educational institutions have at their disposable and the way this budget is actually spent. They include the number of teachers, their salary, expenditures on learning tools, student-teacher ratio, other school expenditures, school size. Although there is widespread disagreement as to the effects on those different school expenditures on school achievements, it is nevertheless usually assumed that this a major, if not the essential instrument for educational policy both for efficiency and equity objectives ${ }^{4}$. With regard to the latter, the "positive discrimination" in favour of schools "with problems", i.e. the definition of "priority educational zones", which will receive additional resources for helping overcome the disadvantages of their specific scholarly population, is a current example of that line of thinking.

Finally, one might consider that achievements (be at school or at work...) are also determined by our own decisions about "effort". This is standard in the labour economics literature. To what extent, as far as school pupils are concerned, is "effort" conceptually meaningful and effectively independent of the other factors mentioned above is in my view an open question! The standard economist's view on this would be that a child, at least after a certain age, is making choices

\footnotetext{
${ }^{4}$ The usual reference is Hanusheck (1986). Most recent references are Figlio (1999), Dewey \& al. (2000). The latter includes an extensive updated bibliography.
} 
between work (study) and all the other activities unrelated to schooling (including yawning during class time !) These choices have definite impacts on child's behaviour with respect to schooling even if the child is enrolled in a compulsory educational program. The chosen combination by each person (child) between studying and the other activities is supposed to reflect her preferences given relative prices and time and income constraints. In other words, supposedly there are inherently highly motivated, strongly working kids who like to study and there are bored, lazy ones who don't. Given their respective preferences, they are making observable choices because they manifest themselves, so the argument goes, under the form of "deviant" behaviour: class disruptions, repeated evaluation failures, drop-outs, and the like for the lazy ones on one hand or high scores test, regularity, punctuality for the highly motivated ones on the other. A moment of reflection suggests that it might not be that simple or self-evident. Class and study behaviour might not be exclusively, or even predominantly if at all determined by "preferences", by "pure free will" or "ambition". The relevance of those concepts in the context of schooling behaviour will be discussed more extensively in section 3 . However, let us suppose at this stage, to be consistent with the ethics of responsibility framework that we are going to analyse, that effort, or ambition, or "pure will", might be unambiguously defined and is an effective determinant of a child's schooling behaviour. A standard school achievement production function would then look like the following.

$$
\begin{gathered}
I_{i t}=f\left(e_{i t}, r_{i t}, h_{i t}\right) \\
\text { with } \frac{\partial f}{\partial e_{i t}} \geq 0, \frac{\partial f}{\partial r_{i t}} \geq 0, \frac{\partial f}{\partial h_{i t}} \geq 0 \\
\text { and } f\left(e_{i t}, 0, h_{i t}\right)=0
\end{gathered}
$$

where $I_{i t}$ is the effective school achievement by child $I$ or his realised investment at the end of period $t, e_{i t}$ is "pure effort", $r_{i t}$, the public resources allocated to child $i$ (student-teacher ratio, teacher salary, expenditures per student on pedagogical equipment, and the like). Last, $h_{\text {it }}$ might be a vector variable or an index variable lumping together all the exogenous factors, i.e. the handicaps or talents of that child $i$, that affect child's behaviour in the schooling process aside from school resources $r_{i t}$ already taken into account ${ }^{5}$. It must be emphasised that $f$ is the "universal transformation function" that converts all the $\{e, r, h\}$ combinations into a given level of $I$ and is thus not personspecific $^{6}$. Again, we will not so far say very much about the precise functional form of (1) although as we will see later on, it is of key importance for the fairness issue. Let us just say, as indicated above, that it is reasonable to say that all partial derivatives will be greater or equal to zero and that the absence of any school resources makes school achievements impossible. The issue of the more precise functional form of (1) will be taken up later.

Using such very simple analytical framework, we might now ask ourselves what would be a "fair" educational system? There are no simple answers to this question.

First, what opportunities do we want to equalise ? Access to schools? Access to degrees ? Access to jobs ? Access to "income prospects"? The extent of justice within society is a matter for everyone's conscience and socio-political views and we might have diverging opinions about this. The collective matter can only be settled by a democratic process ${ }^{7}$. The following discussion will assume that consensus could at least be achieved on the following: the minimally appropriate objective of an equal opportunity policy would be to give to every person the same chances to get the job she will feel appropriate to her given her own personal characteristics (including the formal education she has received) when entering the labour market. This requires at least that each child, whatever her talents, handicaps and background, should have the same opportunity of pursuing her study to

\footnotetext{
${ }^{5}$ The metric used for measuring those variables are of course an entire issue in itself and will not be discussed here. For a general discussion of this type of function, see Belfield (2000)

${ }^{6}$ This does not amount to assuming that all children have the same learning efficiency but it makes all differences in efficiency dependant upon the variables in the argument of the $f$ function.

${ }^{7}$ With all the difficulties that we know are related to democratic decision-making but are beyond the scope of our present discussion.
} 
get the degree most appropriate to her. As a consequence and for all practical purposes, all children should be given equal opportunities to successfully complete the entire general secondary level education $^{8}$. In an increasingly "knowledge based economy", such a level of formal education is becoming a basic necessity for any child to subsequently either study or work in a way that hopefully will allow for some degree of self-fulfilment.

Second, some basic distinctions might be useful. Had we not defined the $f$ function with the variable $e$ in its argument, equality of opportunity would be then be equivalent to equality of outcomes, each one of them requiring equal "extended resources", i.e. an identical combination of $\{r, h\}$. However, the ethics of responsibility recognises that free persons are making voluntary choices in conducting their life as implied by the $f\left(e_{i t}, r_{i t}, h_{i t}\right)$ formulation. Second, some basic distinctions might be useful. Had we not defined the $f$ function with the variable $e$ in its argument, equality of opportunity would be then be equivalent to equality of outcomes, each one of them requiring equal "extended resources", i.e. an identical combination of $\{r, h\}$. However, the ethics of responsibility recognises that free persons are making voluntary choices in conducting their life as implied by the formulation. Free persons should then assume the responsibility for the consequences of those choices, in terms either of rewards or penalties. Equality of outcomes (everyone should obtain a given degree) becomes questionable since such a policy would not take into account differences in preferences among persons. By not doing so, such a policy will unfairly treat those who are putting a very strong effort to achieve such outcome (hard working children) relatively to those who do not. The existence of significant differences in preferences and their consequences for the outcomes implies that equality of outcomes can no longer coincide with equality of opportunities. The latter then becomes the

\footnotetext{
${ }^{8}$ More on this and on the implication of equal opportunity in terms of the structure of the program in section 4 .
}

only relevant principle of fairness if one believes in the importance of personal responsibility in the determination of outcomes ${ }^{9}$. But on the other hand that same "ethics of responsibility" recognises that those same persons should be compensated for those factors, i.e. handicaps (or talents?) over which they do not have any control, for which they cannot be held accountable but will affect the outcome of their activity ${ }^{10}$. Failure to do so would be unfair to those who, despite putting the same effort as some others, will not achieve the same outcomes because, let us say, a natural or social handicap (i.e. hard working kids but parents do not bother...).

If we believe that (1) is an adequate representation of a child's school achievement production function, what would be, among all the $r_{i t}$ 's, a just allocation of $R_{t}$, the total amount of resources that public authorities are making available for educational purposes? What will be a "fair" division of $R_{t} ?^{11}$ The approach to the fair division issue of the "ethics of responsibility" is that society should not interfere with the relation between a person's choices and the "spontaneous" consequences for her of those same choices. These two requirements are translated into two principles, each one of them implying a specific allocation rule for $R_{t .}{ }^{12}$ We now turn to the examination of these two principles and their implications in the context of education.

\footnotetext{
${ }^{9}$ In the context of fairness of competition, Arnsperger and DeVillé argue that responsibility might no longer be relevant whenever winner-take-all situations are prevalent.

${ }^{10}$ See for example Van Parijs (1998) for replacing this approach within a general typology of theories of justice. This framework is critically reviewed by Arnsperger \& DeVillé (2000) in the general context of "fairness of competition."

${ }^{11}$ For convenience and to be consistent with our previous definition of , we lump together in $R_{t}$ the general budget expenditures for education and the budget that public authorities decide to use for equal opportunity in education.

${ }^{12}$ The definition of the two principles is due to Fleurbaey (1998) which provides a comprehensive discussion of them, drawing on previous work, i.e. Fleurbaey (1995).
} 


\section{Compensation versus natural reward}

First, the principle of compensation requires that every person that might suffer from a particular handicap should receive additional resources, in comparison to those who do not suffer from such handicap, in order to correct, at least to some extent, such relative disadvantage. In other words, the principle always involves some transfer of resources from the non-handicapped to the handicapped or, if we deal with talents, from the more talented to the less talented in comparison to the rule of equal resources for each child. This amounts to say that inherited talents are collective resources and inherited ("natural") handicaps are collective impediments that, although embedded in persons, do not justify for them either differential claims or differential losses ${ }^{13}$. Assuming it feasible just for the sake of the argument, perfect compensation would imply that outcomes would only be dependent upon "voluntary" choices, effort, free will, whatever each person's level of talents or handicaps and that this relation is independent from any personal characteristics ${ }^{14}$. In the field of education, this could mean that not only children with "unfavourable" social, family background would receive some form of specific help, but also children with low "innate ability for studying" will be compensated for. But that in the end and assuming again complete compensation, a child's school achievements would only depend upon his voluntarily supplied effort, a given amount of effort leading to the same achievements for all children.

Second, there is the principle of natural reward. Its basic idea is simple: there are no reasons whatsoever that would justify society distorting the "natural"

\footnotetext{
${ }^{13}$ There are numerous questions related to the actual design of such a principle. For a survey of these questions, see Van Parijs (1990).

${ }^{14}$ I realise that this might appear ambiguous. It should not. It is just reminding us that $f$ is not indexed over $i$. However it is obvious the functional $f$ might be non linear, its partial derivatives being a function of some of the variables in the argument, in that sense person's specific. The importance of this point will be made clear later on.
}

consequences of each person's choice at least in some domain of life ${ }^{15}$. This implies that the allocation rule should be such that all persons having the same talents or handicaps should receive the same $r_{i t}$, the public resource. As a consequence, $\mathrm{N}$ persons having a given identical level of talents or handicaps,

$h_{i t}=\bar{h}$ for $\forall i, i=1$ toN

and who choose to put the same effort, or pure will,

$$
e_{i t}=\bar{e} \text { for } \forall i, i=1 \text { toN }
$$

into the realisation function $f$, should be rewarded by the same outcome for

$$
I_{i t}=\bar{I}_{t} \text { for } \forall i, i=1 \text { toN } \text {. }
$$

This illustrates the principle of "equal treatment of equals". And as a corollary, for persons endowed with identical talents, the relation between the differences in outcomes and differences in effort will only depend on the functional $f$, identical for all persons. But it does not imply in general that differences in achievements due to differences in effort will be identical whatever the level of talents and resources ${ }^{16}$.

That these two principles are independent of each other can be easily understood. The principle of natural reward determines an allocation rule between persons endowed with identical talents. It does not say anything about what should be the allocation rule between persons, or class of persons, endowed with different levels of talents or handicaps. This is where the principle of compensation comes into play. Note that in both cases, the allocation rule is independent of the

\footnotetext{
${ }^{15}$ Even for those who hold non-paternalistic views, this is clearly open to discussion as a truly general principle if we accept the idea that our lives do not belong only to ourselves.

${ }^{16}$ This would imply a specific assumption about the function $f$. See later.
} 
effort levels performed by each and every person. As a consequence, their implementation might run against efficiency criteria. This is obvious for the principle of compensation. But it is also the case for the principle of natural reward. It forbids for example to give more (less) resources to those who puts more (less) effort into their activities, as we often do when using incentives schemes of the "carrot-and-stick" kind (rewards and punishment). As a consequence, the allocation rule implied by this principle might not be Pareto-efficient ${ }^{17}$. Finally, as already said before, if responsibility does not play any role in outcome determination, the principle of compensation should lead to equality of outcomes. And, on the contrary, this principle becomes irrelevant if responsibility (preferences) is the only determinant of outcomes.

What are the implications of using these two principles for the design of an "equal opportunity" strategy in education? In a series of stimulating papers, Fleurbaey and Trannoy have discussed several aspects of this question ${ }^{18}$. Are these two principles compatible to each other ? Are they satisfactory guiding principles of justice in the realm of education if one wants to achieve the best possible equal opportunity in education? To discuss these questions, let us now turn to the specific applications of the ethics of responsibility framework in the design of an equal opportunity approach in education.

The precise application of the two principles already discussed seems straightforward. The principle of compensation would require that relatively more resources should be allocated to children from low socio-economic background, suffering from cognitive problems for either "natural" or social reasons and relatively less to children with the opposite characteristics. In its most requiring form, it can be expressed as :

$$
\begin{array}{r}
\text { if } e_{i}=e_{j} \text { then it must be that } \\
\forall i, j, f\left(e_{i t}, r_{i t}, h_{i t}\right)=f\left(e_{j t}, r_{j t}, h_{j t}\right)
\end{array}
$$

\footnotetext{
${ }^{17}$ Fleurbaey (1998), op. cit., p. 212

${ }^{18}$ What follows is essentially based upon the following two contributions : Fleurbaey (1998), Trannoy (1999)
}

The principle of natural reward on the other hand would require that all children endowed with the same talents (or handicaps) should receive the same amount of resources. It can thus be expressed in the following way :

$$
\forall i, j, \text { if } h_{i}=h_{j} \text {, then } r_{i}=r_{j}
$$

Combining the two requirements leads to the following proposition: adopt "ability grouping" over classes or even schools, and allocate more resources (better teachers) to low ability grouping and less to high ones $^{19}$. This seems to satisfy both requirements. However, as shown by Fleurbaey, this is not necessarily the case unless a separability condition is imposed on the function $f$ between on one hand effort and on the other talents and resources ${ }^{20}$.

$$
f\left(e_{i t}, r_{i t}, h_{i t}\right)=g\left(e_{i t}, z\left(r_{i t}, h_{i t}\right)\right)
$$

where

$$
z\left(r_{i t}, h_{i t}\right)=f\left(\bar{e}, r_{i t}, h_{i t}\right)
$$

The $z$ function can be understood as an aggregation device operating on resources and talents independently of any individual effort characteristics of the child. To understand the reason for such a condition, let us first recall that the separability condition actually makes the partial derivatives of $z$ (index of extended resources) with respect to $r_{i t}$ and $h_{i t}$ independent of the level of effort ${ }^{21}$. This property guarantees that allocating more to the less endowed and vice and versa will have the same effect on their school achievements whatever their respective effort level. This is of course crucial if the implementation of an equal opportunity scheme has to respect the principle of natural rewards.

A simple example will help to understand. Suppose a population of children that are differentiated by ability levels due to their different socio-economic backgrounds. Assume also just for the sake of the argument that they happen to be segregated among

\footnotetext{
${ }^{19}$ Trannoy (1999), p.61

${ }^{20}$ Fleurbaey (1995), p.40. Kranich (1997) deals with the same issue under incomplete information and finds that in such a case equal opportunity is unfeasible

${ }^{21}$ In other words, the cross partial derivative with respect to $z$ and $e$ is zero.
} 
schools (or classes) in terms of effort. The hardworking students are concentrated in one school, the "lazy" ones in the other. An equal opportunity policy allocates more resources to the low ability children in both schools. If the achievement function $f$ is nonseparable, the elasticity of potential school achievement with respect to resources is also a function of the effort level. It follows from these premises that the same equal opportunity policy will have quite different effects in each of the schools. If this elasticity is a decreasing function of effort, the equal opportunity policy will give better school achievements to hard-working children compared to low-working ones, both of unfavourable socio-economic background. But the difference between the two groups will exceed what would justify the "pure effort" differential. If the elasticity happens to be an increasing function of effort, the situation is even more worrisome for those unwilling to give up on the principle of natural rewards since it could happen that low-effort children will have better school achievements than hard-working ones ${ }^{22}$. In both instances, the principle of natural reward is violated.

Is the $f$ function separable or not is a question whose answer is often presented as an empirical matter. I am not sure it is a purely empirical one, as we will see later. But the advocates of the ethics of responsibility framework, recognising the empirical doubtfulness of the separability assumption, have explored basically two ways out. The first is to appropriately weaken the compensation principle in order to make it compatible with the principle of natural rewards under general conditions, i.e. without separability (Fleurbaey, 1995). The second explores the specifics of the structure of the educational process (Trannoy, 1999).

Instead of strictly equalising the opportunities among children, which amounts to making their relative school achievements depending exclusively on their relative effort, one could imagine weaker versions of

\footnotetext{
${ }^{22}$ In commenting his results, Fleurbaey $(1995$, p.41) is erroneously comparing children with different socioeconomic background, which is not the issue here since they are all assumed to perform the same effort.
}

the compensation principle that would simply require partial compensation: more resources for the less endowed and a guarantee of better school achievements for the higher-working. However, the same separability condition is required even for these weaker versions. The only way to get rid of the separability requirement is to abandon one or the other principle.

The second way is to make use of the fact that schooling is a sequential process. It is year after year that a child is accumulating knowledge. At the beginning of each year, her past accumulated knowledge becomes an exogenous factor along with the other endowments. Formally, this has long been recognised by introducing lags in the $f$ function, where $A_{i t-1}$ is the cumulative of all previous $I_{i t}$, from $t=1$ to $t-1^{23}$.

$$
\begin{gathered}
I_{i t}=f\left(e_{i t}, r_{i t}, h_{i t}, A_{i t-1}\right) \\
\text { where } A_{i t}=\sum_{t=1}^{t} I_{i t}
\end{gathered}
$$

As such, this does not change anything with the problem at hand. It even appears to make it even more complicated since it makes equal opportunity an every year requirement starting from the first year. There is indeed conspicuous evidence that accumulated knowledge $A_{i t-1}$ is a crucial component for further school achievements. However, Trannoy's suggestion is that it actually makes the problem of justice simpler if we recognise that children cannot exercise full responsibility up to a certain age, say $t^{*}$. In other words, this is the common sense idea that to be responsible, i.e. to consciously make choices about the effort you want to put into your own education, you have to be mature which implies having accumulated enough experiences and reflexive capacities. In other words,

$$
I_{i t}=f\left(e_{i t}\left(r_{i t-1}, h_{i t-1}, A_{i t-1}\right), r_{i t}, h_{i t}, A_{i t-1}\right) \text { for } \forall t, 1 \leq t \leq t^{*}-1, t^{*}>1
$$

Effort becomes entirely determined by the other exogenous factors up to $t^{*}$.

And that after a certain age, say $t^{* *}$, the importance of exogenous factors fades out, leaving only (or mainly) effort to determine school achievements ${ }^{24}$.

\footnotetext{
${ }^{23}$ Belfield (2000), op.cit.

${ }^{24}$ Trannoy (1999), .op.cit.
} 
$I_{i t}=f\left(e_{i t}, A_{i t-1}\right)$ for $\forall t, t * * \leq t \leq T, t * *>1$

Nothing a-priori tells us if $t^{*}$ is greater, equal or smaller than $t^{* *}$. If $t^{*}$ is equal to $t^{* *}$, Trannoy correctly argues that the two principles can be fulfilled in a sequence. Since at the end of the $\left(1, t^{*}\right)$ period, all opportunities must have been equalised, the principle of natural reward can be fully implemented afterwards during the period $\left(t^{* \star}, T\right)$, whenever $t^{\star \star} t^{*}$. The problem arises if $t^{* *}<t^{*}$. In this case, during the second period $\left(t^{* *}<t<t^{\star}\right)$, we are back to the initial problem and a choice has to be made between the two principles. In such instance, Trannoy rightly argues that the principle of compensation should prevail, since it allows the principle of natural reward to be fully implemented during the last period $\left(t^{*}<t<T\right)$ when children are most likely to be "mature".

What to conclude from this ? If we follow the ethics of responsibility approach, invest resources in the early years of the school curriculum to equalise as much as possible basic skills among children with widely different endowments. Once this is achieved, children having on the other hand developed their own capacity for making choices, but their "extended resources" having been supposedly equalised, the principle of natural rewards simply requires equal treatment for equals, i. e. for all children the same resources.

This analysis is questionable for several reasons: the concept of responsibility applied to child's behaviour requires important qualifications, the assumptions about child's behaviour are not satisfactory and overlook incentive compatibility problems and the lack of consideration for school functioning neglects important aspects like peer effects, family role in the educational process and teacher's involvement. All those issues have specific ethical implications.

\section{Choices, responsibility and child's schooling behaviour : a re-examination}

The ethics of responsibility in the context of education assumes that effort (or pure will) is one of the key determinants of school achievements by children and that children are after a certain age responsible for the intensity of the effort level that they put into the learning process. This notion of "responsible" effort deserves some clarifying. At the basis of their analysis is the idea that effort is the result of a conscious deliberate "choice". And choices are the expression of a person's preferences and thus ultimately of her freedom in conducting her life.

But between what alternatives is this choice made ? And how is it made ? The standard answer is that what one is concerned with is the choice between work (effort and its related painfulness) and "leisure" (non-work related activities). And such a choice is made according to some kind of optimisation process which could be the maximisation of her own well-being and self-fulfilment.
In other words,

$$
I_{i t}=f\left(e^{*}{ }_{i t}, r_{i t}, h_{i t}\right)
$$

where $e^{*}$ it is the optimal amount of effort, resulting from the optimisation process.

But for a choice to be an expression of freedom and thus as a matter of concern for responsibility, this requires three conditions to be simultaneously fulfilled. First, the ability to make a conscious evaluation of the costs of the alternatives compared to their benefits in regard of one's own preferences. This is the informational aspect of choice as an expression of freedom. Second, the person has to have the ability to carry out a coherent procedure to make the choice ; this is the "rationality" aspect. Finally, and much more importantly, the costs and benefits of each alternative are to be such that a real choice can be made. This last condition might have striking implications: i.e. the more 
important are the stakes from the choice process, the less "real" the choice might actually be. The usual example is the slave who can choose between working for his master or live in prison (or die): his choice could definitely not be considered as an expression of his freedom ${ }^{25}$. This example is the case when external power is exercised over the individual and constrains her choice set. But we can also have the case of "absolute" preferences, i.e. preferences about something that exclude any possible arbitrage between that "thing" that we more or less want and anything else ${ }^{26}$. It is this last possibility that seems to us relevant for the case at hand.

Indeed, what sense does it make to talk about choice in the common sense of the word, for a child of scholarly age? Two alternatives should be contemplated: mandatory schooling and free enrolment in educational programs, i.e. higher education or, for some educational systems, higher secondary education programs. Let us take the case of mandatory schooling.

Children exhibit different degrees of implication, involvement, interest in carrying out their compulsory schooling duties. To what extent could we consider a teenager who "does not like to study" as making a real choice, i.e. exercising her free will according to her own true preferences? A first answer would be to deny such exercise of free will altogether by arguing that the child's effort is itself determined by "nonresponsibility" factors like cognitive abilities, which in turn depend upon contextual factors, or previous school achievements. A child might have weak motivations for study because he has or feels he has little talents, or real handicaps for studying. Or because she does not receive very much parent's or family support... This amounts to recognise that there are two distinct causality channels going from exogenous

\footnotetext{
${ }^{25}$ This justifies the importance of formal freedom as a prerequisite for the exercise of real freedom. Winner-take-all situations are also exemplary of this, see Arnsperger and DeVillé (2000).

${ }^{26}$ Inelastic demand curves are the consequences of "absolute preferences". As a necessary (but not sufficient) condition, this implies separability in the utility function between a specific element in its argument and all the others. Separability implies that the cross partial derivatives are zero.
}

contextual factors to educational achievements, one direct, the other through their influences on preferences and thus on effort itself, as was already done when discussing Trannoy's suggestion of decomposing the schooling process in two periods ${ }^{27}$.

$$
f\left(e_{i t}\left(r_{i t-1}, h_{i t-1}, A_{i t-1}\right), r_{i t}, h_{i t}\right)
$$

But this begs the question by actually assuming, if one stops there, that there is no such a thing as "free will". The real, important question is what could be left of "pure free will" once all these influences are taken into account. What then could be "free will" if it exists?

One could argue, as Roemer (1998) does, that for each population of children of given talents and handicaps there exists an observable distribution of school achievements and thus of effort performed by every child of this population ${ }^{28}$. Those distributions have no reasons to be identical. Their differences are related to "circumstances", the non-controllable factors discussed in the previous section. In other words, what children should be made responsible for is not their absolute effort level but their relative one ${ }^{29}$. The principle of compensation (the allocation rule) must then satisfy the condition that each child belonging to the same centile in any distribution of effort of whatever type must have the same school achievement.

First, we, adults as well as children, are not responsible for our preferences as such. Second, we are however responsible for the voluntary consequences (choices) that we derive from our preferences. But, third, there are also "involuntary" consequences of our preferences in the sense that they are "choices" that are not expression of freedom ${ }^{30}$. For a child, choices about her implication or commitment to study has not

\footnotetext{
${ }^{27}$ This is of course the old, never ending, debate on "endogenous" versus "exogenous" preferences. For a discussion within the framework of "equal opportunity", see Fleurbaey (1998), in more general terms, Arnsperger and DeVillé (2001)

${ }_{28}^{2}$ Roemer (1998), pp.13-23

${ }^{29}$ The metric, proposed by Roemer, of the measure of the relative effort of a child is the centile he belongs to in the effort distribution of his type.

30 "Addiction" would be the most common sense example of a separability characteristic in the utility function
} 
very much to do with the choice between labour and leisure, not alone the one with maximising the expected net income streams from additional year of schooling. Children do have "preferences" about studying but it is not between studying and something else: this what we called above "absolute preferences". The best words to describe those preferences are "motivation", "desire" or "eagerness" 31. These are behavioural characteristics that respond to particular types of stimuli: relevance to his/her own life experience, game-like aspects, taste for abstraction, curiosity, etc. The intensity of this "preference" might vary substantially from one child to another, and so will her involvement and personal implication in the schooling process ${ }^{32}$. If we agree with this, then it is clear that the principle of natural reward has no places in here as a principle of justice since a child's effort cannot be considered as the expression of freedom of choice in the usual sense but much more as the expression of inner characteristics, of her personality. If the above reasoning is correct, pure effort

$\overline{e_{i t}}$ happens to be like a "pure talent", non-correlated

to any other contextual elements, once those have already been taken into account in the vector of extended resources $\{r, h\}$.

$$
f\left(e_{i t}\left(\overline{e_{i t}}, r_{i t-1}, h_{i t-1}, A_{i t-1}\right), r_{i t}, h_{i t}\right)
$$

What are the implications of this for the equal opportunity approach in education? First, as we already hinted just before, the problem of the incompatibility between the two principles is no longer relevant. Only the principle of compensation should matter. The formulation (2), ensuring that the same effort will achieve the same outcome for every pair of individuals, remains entirely valid. But it is no longer required to have separability in the school achievement func-

\footnotetext{
${ }^{31}$ Dworkin talks about "ambition", Arneson and Cohen about "power of the will" but of course all of them makes it a matter of responsibility, which I don't.

${ }^{32}$ In more technical terms, one could argue that children have

"utility functions" but that they are separable with respect to effort in education. The point is made in slightly different terms by Trannoy (1999), p.63.
}

tion as was the case in (4) and (5). In addition, the idea of decomposing the schooling process into two periods, one where exogenous factors are the exclusive determinants of school achievements and the other where effort is the result of "free will" becomes no longer relevant.

Different effort intensities will entail different school achievements and this throughout the entire compulsory schooling period. Having argued that it is not a matter of responsibility might suggest that we treat those differences exactly as differences in the other talents or handicaps, i.e. to use resources to equalise those differences. The equal opportunity approach should then be abandoned altogether. In the absence of any responsibility factor, only equality of outcomes would then remain as a meaningful principle of justice that should govern the allocation of resources in the educational system. But should we go along this line of thought? I do not think so. An argument can be made that those differences in effort, motivation or whatever reflect fundamental differences among human beings, who are fundamentally heterogeneous. Exactly in the same way as we argue for adults that there is no single common, universal conception of the "good life", we should accept that children do not have a single common view of what is a good, satisfactory and adequate level of schooling achievements. In this regard, justice requires to go beyond compensation of handicaps and should aim at equality of opportunities in a more extensive sense by providing adequate opportunities for everyone to follow the educational curriculum most appropriate for her own specific motivations and expectations ${ }^{33}$. This requires a specific organisation of school programs combining a general curriculum common to all children especially at the start of the schooling process with increasingly, carefully designed diversification through the possible access to various types of options.

\footnotetext{
${ }^{33}$ This raises the issue of "valid" preferences: it is not because you want to become an engineer although you are not the best fit for that, that society should invest all the needed resources to give you the best chances for getting that degree.
} 


\section{More on the child's schooling achievement function: complementarity and school organisation}

The compensation principle is based upon the assumption that substituability among determinants of schooling achievement other than effort itself is important. In other words, handicaps can be effectively compensated by additional resources devoted to the child by making her "extended resources" identical to those more favoured children. This is a key assumption. More resources can indeed mean both quantity and quality improvements of the inputs of the educational process: better paid high quality teachers, more individualised aid for each child, increased availability of school infrastructures, better equipment's are factors that, taken together, might be helpful in overcoming low cognitive abilities due to handicaps of various kinds.

But they might not be sufficient to effectively improve school achievements if they are not accompanied by two other elements: an increasing effort level on the part of the children and an effective organisational functioning on the part of the school.

Effort and other educational resources might actually be complements to each other. As a consequence, the school achievement function (1) has to be specified by making effort and other factors complements rather than substitutes. As an example and using the formulation of equation (4), the school achievement function could be specified as a quasi-Leontief function where $\alpha$ and $\beta$ are unit input requirements.

$f\left(e_{i t}\left(\overline{e_{i t}}, r_{i t-1}, h_{i t-1}, A_{i t-1}\right), r_{i t}, h_{i t}\right)=\min \left\{\frac{e_{i t}\left(\overline{e_{i t}}, r_{i t-1}, h_{i t-1}, A_{i t-1}\right)}{\alpha}, \frac{z\left(r_{i t}, h_{i t}\right)}{\beta}\right\}$

This simple formulation suggests that an equal opportunity strategy, to be effective, has to deal not only with the compensation of different handicaps, talents and other exogenous factors that determine learning capacities but also with the related motivational aspects, symbolised here by the $\overline{e_{i t}}$ variable. Pouring simply more resources into the system will not be enough to achieve a true equal opportunity situation if the incentives aspects con- cerning the motivational aspects of the behaviour of the children, the parents and the teachers are not dealt with.

What indeed are the incentive compatibility problems that an equal opportunity strategy might run into?

First, children might be induced to decrease their effort level because of the additional resources that they might get. This would be particularly true for those who have the most handicaps and the least favourable environment. Since it is likely that on the average those children would tend to put lower effort, this as such should not concern us because the objective of the policy is not to maximize average effort per se but to give the chance to everyone to achieve as high as possible a level of school achievement. However, if effort, as suggested above, is a complement to resources and talents, there is a reason to promote effort as much as possible. One way of doing this, which might be considered by the child as a real reward, is to give her in relation to her relative score performance the possibility of realizing, for example during vacation time, a "project" that has both intellectual and entertainment values.

It has also been consistently established that family involvement might be extremely helpful in bringing up the motivations for study of the children. Parents motivations for such an involvement clearly depends on the time constraints they are faced with, their "studyculture" One possibility would be to make for lowincome families supplementary children benefits partly related to the more successful completion (better scores or improved scores) of school requirements relative to the average score of children of the same type.

Teacher's involvement in dealing with low ability children is certainly more requiring and exhausting than with high ability ones. An equal opportunity strategy will justify payment of special compensation for teachers who accept this challenge. But as it is often the 
case, it is not so much a question of additional wage payments but of smaller teaching loads, more frequent sabbatical leave for rethinking the pedagogy and the content of the courses and better support for developing a more personalised pedagogy for children with handicaps.

Finally, it should be apparent that the formulation of (4c) bypasses one crucial but often neglected aspect of a meaningful equal opportunity strategy. It exclusively focuses the attention on child's behaviour and its determinants. But the variable $r_{i t}$, resources as an input in the child's schooling achievement function, is also produced by the school itself, primarily through the quality and quantity of the teacher's involvement in the pedagogical process as we have already discussed but also through its organisational features. The efficiency levels of schools vary significantly and, as many studies have shown, inefficient schools tend to be concentrated in areas where the proportion of less favoured children is higher. On the other hand, best practices schools are most often the most equitable because their efficiency gains is translated

\section{Concluding remarks}

The preceding discussion could be summarised in the following way. A "just" educational system should give the opportunity for every child, whatever her background, social origin, specific abilities, to achieve the highest possible general education level that will enable her to further study or compete for jobs appropriate to her own characteristics ${ }^{36}$.

\footnotetext{
${ }^{34}$ A recent study made by the French Ministry of Education (DPD, Direction de la Programmation et du Développement) shows that $25 \%$ of the secondary level public schools could be considered as being confronted with difficult, even severe situations and those establishments regroup four times as much low socio-economic background children as the average public school.
}

mainly in improved school achievements for the children doing worst than the average ${ }^{34}$. This suggests that schools with predominantly low ability children are faced with particularly severe organisational challenges and that they should receive specific help to overcome those difficulties.

Does an equal opportunity strategy require, to be implemented, "ability grouping" which by definition is detrimental to the "peer effects", i.e. the positive externalities created by the interaction between low ability and high ability students in the same class room and in the same school? I am not so sure. One could imagine most of the tools used for such a strategy being designed on an individual basis. However, we know that there are spontaneous forces that lead to segregation in terms of ability of scholarly populations among schools. An equal opportunity strategy will have to carefully balance the measures that should work against such a segregation with those that are designed taking into account the existence of such a segregation but might reinforce $\mathrm{it}^{35}$.

To achieve such an objective requires the implementation of policy measures (compensation principle) that will both compensate for differential in talents or handicaps and enhance the learning motivation of the children. In particular, every achievement by low ability children should lead to some concrete recognisance of what has been achieved and to some new incentives to sustain that effort given the new possibili-

\footnotetext{
${ }^{35}$ The ZEP (Zone d'Education Prioritaire, Priority Educational Zone) are among those measures.

${ }^{36}$ Which could be the degree corresponding to the compulsory school curriculum. One reminds, as said before, that in Belgium, where schooling is compulsory until the age of eighteen, it is estimated that $40 \%$ of the children of a given age cohort do not complete successfully the entire curriculum.
} 
ties that it opens for the child. Finally, this policy to be effective should also promote the involvement of teachers and parents.

For the implementation of a "principle of compensation" that has "build-in" incentives designed to support positive motivational change for less favoured children and to favour parents and teachers involvement, one could consider the following policy proposals:

- An personalised educational project for every child, requiring specific school organisation, team structuring and personal tutoring for low ability children

- Common core program for all children but with increasing number of options, excluding formal ability grouping or tracking

- Centrally organised children evaluation that will allow teachers to better identify the personal characteristics of their pupils. However, in using such evaluation, one has to be careful about perverse signalling (stigmatisation) both of children and of schools that could lead to adverse selection problems and about the danger of inducing "perverse" teacher's behaviour, (team work and rewards are probably essential here)

- Teacher's supplementary benefits: subsidies to teachers for their involvement in difficult schools, and additional marginal subsidies (special training, lower teaching load, sabbatical years for better than average results) related to their class performances (this requires outside evaluation, see above)

- For low income families, supplementary real income allowances for each successfully completed year of schooling, and ...

- $\quad$ "in kind" (based on an "extra-curriculum" activity project involving the family and discussed with the child's teachers...) and not "in pure money" terms, one being careful in both cases about not making the children instrumentalised by their parents who would be eager to maximise the income effect of their children success in school.

- Incentives for maximising peer effects: small group organisation for out of class work and rewards for classes narrowing the variance of the scores of a comprehensive evaluation by improving the lowest scores. 


\section{References}

Arnsperger Ch. \& P. DeVillé (2001), "Can competition ever be fair ? Challenging the standard prejudice", IRES Discussion Papers, $\mathrm{n}^{\circ} 16,32 \mathrm{pp}$.

Belfield, C.R. (2000), Economic Principles for Education, ch.4, 72-95.

Dewey, J., Th. Usted \& L. Kenny (2000), "The ineffectiveness of school inputs : a product of misspecification ?", Economics of Education Review, 19, 27-40

Figlio, D.N. (1999), "Functional form and the estimated effects of school resources", Economics of Education Review, 18, 241-252

Fleurbaey, M. (1995), "The requisites of equal opportunity", in Barnett, W.A., H. Moulin, M. Salles \& N.J. Schofield, Social Choice, Welfare, and Ethics, Cambridge (UK), Cambridge University Press, ch. 2, pp. 37-53

Fleurbaey, M. (1998), "Equality among responsible individuals", in Laslier J.F., M. Fleurbaey, N. Gravel \& A. Trannoy (eds.), Freedom in Economics: new perspectives in normative analysis, London, Routledge, ch. 15, pp. 208 and foll.

Fleurbaey, M., R. Gary-Bobo and D. Maguain (2000), "Education, Distributive Justice, and Adverse Selection", Thema Research Papers, Univ. Cergy-Pontoise, 14.

Hanushek, E. (1986), "The Economics of Schooling: Productive and Efficiency in Public Schools", Journal of Economic Literature, 24, September, 1141-77

Laslier J.F., M. Fleurbaey, N. Gravel \& A. Trannoy (eds.) (1998), Freedom in Economics: new perspectives in normative analysis, London, Routledge, ch. 15, pp. 208 and foll.

Levin, H.M. (1994), "The necessary and sufficient conditions for achieving educational equity", in Berne R. \& L. Pincus, (eds), Outcome Equity in Education, Thousand Oaks (CA), Corwin Press

Marlowe, M.L. (2000), "Spending, school structure and public education quality", Economics of Education Review, 19, 89106

Roemer, J. (1998), Equal Opportunity, Cambridge, MA, Harvard University Press

Trannoy, A. (1999), "L'égalisation des savoirs de base: l'éclairage des théories économiques de la responsabilité et des contrats", in Meuret, D.,(ed.), La justice du système éducatif, Paris, De Boeck, ch. 3, pp. 56-76

Van Parijs, Ph. (1990), Qu'est-ce qu'une société juste ?, Paris, Le Seuil

Van Parijs, Ph. (1998), Justice as the fair distribution of freedom, in Laslier J.F., M. Fleurbaey, N. Gravel \& A. Trannoy, (eds.), Freedom in Economics: new perspectives in normative analysis, London, Routledge, ch. 14, pp. 197 and foll.

Zachary, D. \& V. Dupriez (1999), "Structures scolaires et équité pédagogique", in Gazier, Outin and Audier, (eds.), L'économie sociale. Formes d'organisation et institutions, Actes des XIXèmes journées de l'AES, Paris, L'Harmattan 


\title{
Cahiers de Recherche du GIRSEF
}

\author{
Déjà Parus :
}

Thiéry F., Zachary M-D., De Villé Ph., Vandenberghe V. (1999) Enseignement initial : les enjeux du développement de l'enseignement supérieur sur fond de crise de l'enseignement secondaire qualifiant, Les cahiers de Recherche du GIRSEF, $\mathrm{n}^{\circ}$ 1.

Conter B., Maroy C., Urger F. (1999) Le développement de la formation professionnelle continue en Belgique francophone, Les cahiers de Recherche du GIRSEF, $\mathrm{n}^{\circ} 2$.

Vandenberghe V. (1999) Regard rétrospectif sur la dynamique des dépenses d'enseignement en Communauté française de Belgique :1988-1998, Les cahiers de Recherche du GIRSEF, $\mathrm{n}^{\circ} 3$.

Dupriez V., Maroy C. (1999) Politiques scolaires et coordination de l'action, Les cahiers de Recherche du GIRSEF, $\mathrm{n}^{\circ} 4$.

Doray, P. (2000) Les articulations entre formation professionnelle initiale et formation continue au Québec :quelques pistes de travail, Les cahiers de Recherche du GIRSEF, $\mathrm{n}^{\circ} 5$.

Casalfiore S. (2000) L'activité des enseignants en classe. Contribution à la compréhension de la réalité professionnelle des enseignants, Les cahiers de Recherche du GIRSEF, n 6 .

Vandenberghe V. et Zachary M-D. (2000) Efficacité-équité dans l'enseignement secondaire de la Communauté Wallonie Bruxelles : essai d'évaluation dans le cadre d'une comparaison internationale, Les cahiers de Recherche du GIRSEF, $n^{\circ} 7$.

Vandenberghe V. (2000) Enseignement et iniquité : singularités de la question en Communauté Wallonie-Bruxelles, Les cahiers de Recherche du GIRSEF, $\mathrm{n}^{\circ} 8$.

Guyot J.-L., Bonami M. (2000) Modes de structuration du travail professoral et logiques disciplinaires à l'Université, Les cahiers de Recherche du GIRSEF, $\mathrm{n}^{\circ} 9$.

Cattonar B. (2001) Les identités professionnelles enseignantes. Ebauche d'un cadre d'analyse. Les cahiers de Recherche du GIRSEF, $\mathrm{n}^{\circ} 10$.

Maroy C. et Doray, P. (2001) La construction des relations écoles / entreprises. Le cas de la formation en alternance en Communauté Française de Belgique et au Québec, Les cahiers de Recherche du GIRSEF, n¹1.

Maroy C. (2001) Le modèle du praticien réflexif à l'épreuve de l'enquête, Les cahiers de Recherche du GIRSEF, n¹2.

Mangez E. (2002) Régulation et complexité des rapports familles - écoles, Les cahiers de Recherche du GIRSEF, n¹3.

Waltenberg F. D. (2002) Polarisation et appariements sélectifs des individus. Etat de la question, Les cahiers de Recherche du GIRSEF, n¹4.

Waltenberg F. D. et Vandenberghe V. (2002) Etat des lieux de mobilité des élèves en cours de scolarité primaire en Communauté française Wallonie - Bruxelles. Une analyse économique et quantitative, Les cahiers de Recherche du GIRSEF, $\mathrm{n}^{\circ} 15$.

Casalfiore S. (2002) Les petits conflits quotidiens dans les classes de l'enseignement secondaire. I. Nature et sens des transgressions sociales à l'origine des conflits dans la dyade enseignant-élève, Les cahiers de Recherche du GIRSEF, n¹6 


\section{Cahiers de Recherche du GIRSEF}

Dauphin N. et Verhoeven M. (2002) La mobilité scolaire au cœur des transformations du système scolaire. Les cahiers de Recherche du GIRSEF, n¹9.

Casalfiore S. (2003) Les petits conflits quotidiens dans les classes de l'enseignement secondaire. II. Nature des stratégies de résolution, Les cahiers de Recherche du GIRSEF, n²0

Casalfiore S. (2003) Les petits conflits quotidiens dans les classes de l'enseignement secondaire. III. Conception de l'autorité chez les élèves, Les cahiers de Recherche du GIRSEF, $n^{\circ} 21$

Vandenberghe V. (2003) Un enseignement secondaire technique et professionnel (dé)valorisé ?, Les cahiers de Recherche du GIRSEF, n²2

Dupriez V. (2003) La coordination du travail dans les établissements scolaires : les différentes voies de construction de l'accord, Les cahiers de Recherche du GIRSEF, $\mathrm{n}^{\circ} 23$

Si vous souhaitez obtenir d'autres numéros de ces cahiers, vous pouvez les obtenir au secrétariat du GIRSEF au prix unitaire de $6 €$, Place Montesquieu 1 bte 14, B-1348 Louvain-la-Neuve, Tél : 32-10-472066, Fax : 32-10472400, email : girsef@anso.ucl.ac.be

Un résumé des textes parus dans ces cahiers est disponible sur le Web à l'adresse suivante : http://www.girsef. ucl.ac.be/cahiers.html. 